\title{
Editorial Foreword 73.2 (May 2014)
}

\section{Our Cover}

This issue's cover is inspired by the pair of essays discussing the Soviet influence on science fiction and technology throughout the communist domain of the Cold War era. It is a composite of images of stamps issued in North Korea, the main focus of the lead piece in the pair. Although the stamps were produced in the late 1980s, they commemorate key moments and individuals in early Soviet space exploration: Konstantin Tsiolkovski (1857-1935), who was a Russian (later Soviet) rocket scientist whose interest in astronautics led him to come up with the ideal rocket equation; Sputnik 1, the first artificial Earth satellite, launched in 1957; Laika the dog, the first living being to make it into orbit; and Valentina Vladimirovna Tereshkova, who, in 1963, was the first woman to fly into space, and is still the only woman to fly solo. Her commitment to space continues; in 2013 she offered to go on a one-way trip to Mars if the opportunity arose. These images are used with permission from Depositphotos, and are described as follows: DEMOCRATIC'S [sic] REPUBLIC (DPR) of KOREA - CIRCA 1987: A stamp printed in DPR Korea (North Korea) shows 30 anniversary of the first flight satellite, Sputnik-1 1957, circa 1987 ID 23073540; DEMOCRATIC'S [sic] REPUBLIC (DPR) of KOREA - CIRCA 1987: A stamp printed in DPR Korea (North Korea) shows Wright 30 anniversary of the first flight inhabited, dog, circa 1987 ID 23073508; DPR KOREA - CIRCA 1985: A stamp printed in DPR KOREA (North Korea) shows Konstantin Tsiolkovski, circa 1985 ID 12168024; KOREA CIRCA 1988: stamp printed by Korea, shows Valentina Vladimirovna Tereshkova, circa 1988. ID 3117889. Depositphotos, http://depositphotos.com (accessed February 28, 2004).

This issue's diversity is striking. In terms of discipline and topic, readers will find historians, literary specialists, historians of art, and a social scientist, working the borders between anthropology and sociology, discussing everything from the influence of European existentialism on intellectuals in Southeast Asia to Buddhist iconography and the economic and human dimensions of Asia's integration into global patterns of sportswear production. In terms of geographical and temporal concerns, the articles that follow move through time from the seventeenth century to the contemporary era and through space from Henan to Hanoi and Bangkok to Bangladesh. Actually, one could go much further than that and say that they move as well from the past and the present into the future and from Earth to Mars and the Moon. This is because, in addition to discussions of more grounded topics, the issue includes writing on science fiction. 


\section{REFLECTIONS}

This issue begins with a set of three short essays, collectively titled "Further Reflections on Partition," that builds upon and in part reacts to the discussion of Partition in South Asia that opened the previous issue. More details about this trio of commentaries is provided in a brief Editor's Introduction to the section below.

\section{Asia Beyond the Headlines}

The next essay in the issue, which continues our "Asia Beyond the Headlines" series, is by Wolfram Manzenreiter of the University of Vienna. Titled "Playing by Unfair Rules? Asia's Positioning within Global Sports Production Networks," it deals with both broad economic trends associated with globalization and the tragic human toll of events such as the collapse of a factory building in Dhaka, Bangladesh, that cost the lives of more than a thousand workers.

\section{Research Articles}

Our research articles begin by trekking beyond the bounds of earth with DAFNA ZuR's "Let's Go to the Moon: Science Fiction in the North Korean Children's Magazine Adong Munhak, 1956-1965," as well as a "Comment" on her piece by Nicolai Volland. The authors share an interest in the transnational circulation not of goods and fashion but of fantasies of extraterrestrial exploration. Long before any Asian countries were prime players in an actual space race-as China and India in particular are today-Zur makes clear, young readers in North Korea were devouring stories about rocket ships and also, as explorers who go down instead of up have been familiar parts of the genre since Jules Verne's time, deep-sea diving adventures. Volland's supplement to Zur's article extends the discussion of space travel stories westward from the Korean peninsula to take in fantastical tales produced and consumed in China during the Mao era. A key theme linking Zur's analysis and Volland's short follow-up piece is the influence that Soviet literary forms, as well as Five-Year Plans, aid packages, and technical and economic advisers, had on both China and North Korea early in the Cold War era.

The next two articles, by Singapore-based historian of science SAMSON W. LIM and historian WyNn GADKAR-WILCOX of Western Connecticut State University, take us from Northeast Asia and China down to Southeast Asia. The former's "Murder! in Thailand's Vernacular Press," which explores issues ranging from censorship to political violence and sensationalistic reporting, offers an intriguing window onto the ways that political history and the history of journalism can become intertwined. The latter's "Existentialism and Intellectual Culture in South Vietnam," meanwhile, looks at why works by Malraux, Camus, and Sartre had such appeal in the "intellectual marketplace" of 1960s Saigon.

The next two articles take readers back in time: to the 1600s in the case of SAMUEL Wright's "From Praśasti to Political Culture: The Nadia Raj and Malla Dynasty in Seventeenth-Century Bengal," and then a less distant part of the past in art historian Wen-shing Chou's "Reimagining the Buddhist Universe: Pilgrimage and Cosmography 
in the Court of the Thirteenth Dalai Lama (1876-1933)." Both offer sophisticated and detailed analyses of difficult-to-parse documents laden with significant inscriptions in the one case, paintings in the other.

The next two articles, by historians Kathryn Jean Edgerton-Tarpley and Rebecca Jane Williams, focus on different parts of Asia but show a common concern with the human consequences of state intervention. The former's article, "From 'Nourish the People' to 'Sacrifice for the Nation': Changing Responses to Disaster in Late Imperial and Modern China," explores continuities and discontinuities in the ways that three governing organizations - the Qing dynasty, Chiang Kai-shek's Nationalist Party, and Mao Zedong's Communist Party-handled catastrophic events. Williams's "Storming the Citadels of Poverty: Family Planning under the Emergency in India, 1975-1977" zeroes in on a very specific point in time to ask "why family planning became such an important point of state intervention" at that particular moment.

Finally, before the issue closes, as always, with a rich array of book reviews dealing with disparate parts of Asia and comparative and theoretical issues that focus in part on Asian settings, comes a last research article: historian Kinsten L. ZiomeK's "The 1903 Human Pavilion: Colonial Realities and Subaltern Subjectivities in TwentiethCentury Japan." This essay analyzes the issues associated with ideas about race, ethnicity, citizenship, and backwardness that were generated by a debate that swirled around whether it was appropriate or reprehensible, as all readers would surely now agree was the case, to put an Ainu man on public display at an exhibition as if he were an animal in a zoo.

-JNW

\section{Forthcoming Articles in $J A S 73.3$ (August 2014)}

\section{Research Articles}

Tobacco, God, and Books: The Perils of Barbarism in Eighteenth-Century Korea Gregory N. Evon

Pan-Asianism and Religion: The Reception of Islam and Translations of the Qur'ān in Twentieth-Century Japan

Hans Martin Kraemer

"Extreme Confusion and Disorder?" The Japanese Economy in the Great Kantō Earthquake of 1923

Janet Hunter

Intimate Desires: Dalit Women and Religious Conversions in Colonial India Charu Gupta

"In Search of New Voices from Alien Lands": Lu Xun, Cultural Exchange, and the Myth of Sino-Japanese Friendship

Eileen Cheng 
Sergeant-Major Gandhi: Indian Nationalism and Nonviolent "Martiality" Maria MisRa

The Fortunes of a Scholar: When the Yijing Challenged Modern Astronomy StÉPHanie Homola

Buddhism and Militarism in Northern Thailand: Solving the Puzzle of the Saint Khruubaa Srivichai Katherine Ann Bowie 